\title{
Different Measures of Social Class - Different Results of Class Voting? The Colombian Case
}

\author{
JAN PUMR* \\ Různé př́stupy $\mathrm{k}$ měření sociálních tříd - odlišné výsledky tř́ídně \\ podmíněného volebního chování? Př́ípad Kolumbie
}

\begin{abstract}
Class based electoral behaviour belongs to topics that have been subject of research for many decades; especially in developed Western countries. The class structure is a basis for class voting research. The EGP scheme is a most widespread model of social structure. This scheme is based on the employment structure; some authors prefer other models based for example. On the number of assets of each household or on the household income. This paper attempts to test different stratification models using the Colombia example to see whether class voting results will differ significantly or whether certain matches will be found.
\end{abstract}

Keywords: Colombia; class voting; social class; household wealth; household income; EGP

DOI: $10.14712 / 23363525.2021 .2$

\section{Introduction}

In June 2018 the right wing won the presidential election in Colombia again. However what's more important is the fact that it was a much more right-wing candidate than Juan Manuel Santos. Iván Duque, whose prominent supporter is former Colombian president and current senator Álvaro Uribe, defeated the leftist and progressive candidate Gustavo Petro in the second round of elections. Two important topics became a symbol of these elections accompagnied with fear. On the one hand, the issue of a peaceful agreement with the guerrilla group FARC-EP and the fear of Petro's voters, that in the case of Duque's victory, the peace treaty will be greatly revised resulting in the resumption of the civil war that has only recently ended after about 50 years. On the other hand, the theme of the economic system and development and the fear of Duque's voters, that in the case of Petro's victory, the new administration would introduce a socialist system, which would pave the way to a Venezuelan style major economic and humanitarian crisis. Moreover, this fear is exacerbated by the enormous number of Venezuelan refugees who chose to flee to neighbouring countries away from the crisis, but most often in Colombia.

What is the role of the class membership in this electoral result? The details are not yet available, but it is still possible to consider the past years experience. We can look back and examine whether there was any phenomenon in the past years that would explain the electoral behaviour of individual classes in Colombia. The first step in the investigation of class-based electoral behaviour is the choice of an appropriate stratification model. Anyway, which model of social class structure should we choose?

\footnotetext{
* Mgr. Jan Pumr, Philosophical faculty of Hradec Králové University, Rokitanského 62, 50003 Hradec Králové. E-mail: jan.pumr@me.com. Researcher ID: V-4126-2018.
} 
The goal of this article is twofold. At first it will offer a comparison of existing and most frequently used social class models and compare and analyze the results of classbased electoral behaviour using these models. The second goal is to examine the transformation of electoral behaviour in individual stratification models between 2006/7 and 2012/13. Why these years? The mentioned periods are relatively important milestones in modern history of Colombia. In 2006 and 2007, President Álvaro Uribe launched his second term when dynamics of the armed conflict between government units and the FARC-EP changed significantly. Reinforced military forces gained considerable successes, with the help of paramilitares having forced many guerrillas out of many territories. It was also a period of significant support from civilian population for president Uribe and his militant strategy [LaRosa - Mejía 2017]. 2012 and 2013 were the years of the beginning of peace negotiations between the Santos administration and the FARC-EP, which finally led to the signing of the peace agreements in September 2016 in Cartagena.

At the same time, the article brings up a few questions. Are the results of each model significantly different, or are there some consistent features? And did the electoral behaviour change between 2006/7 and 2012/13 in each stratification model of the social classes? Is there any explanation for the voting behaviour of each social class?

One hypothesis says that if we compare different stratification models, the first one based on occupation levels and the second one based on socio-economical levels, we can find certain consistent features. It is obvious that the service class (EGP) will include a lot of the same individuals of the highest class of the socio-economic model based on the wealth index. And the class of poor self-employed will share the same objectives and goals as the lowest class with low wealth index. Similar findings can also lead to a belief in the data reliability of the AmericasBarometer database, which of course would be very positive. The area/region variables are also very important in the case of such a geographically diversified country as Colombia. Historically, there were many territories that the central government had no control over, due to very specific geographical conditions in Colombia, the presence of three mountain ranges, many small valleys or dense jungle [Safford - Palacios 2002]. Instead of the central government, in outlying regions local leaders have often wielded power and the traditional parties relied on them to secure the support in rural areas, which led to massive clientelism [Hartlyn - Dugas 1999] and influenced the voting behaviour.

In some works, the conceptualization of a class analysis is also present. Although this article will not have such an ambition, it will present in the first part current and most used models of social structure and a short review of recent literature. The second part will cover the data, stratification models and methods which will be used to calculate the class voting in this article, and finally the third part will offer the results and analyzes of class-based behaviour in Colombia using different stratification models in 2006/7 and 2012/13.

\section{Actual approaches to measuring of social class}

Previous works are based mainly on the Marxist concept of class structure, where the people's relationship to the means of production is of primarily importance. In a post-industrial society with service sector development, this concept is untenable, and therefore later works are more and more often working with the neo-Weberian concept of class 
analysis that represents the social structure as a group of individuals who hold a similar position on the labour market (therefore, it is not directly related to the means of production) and thus have similar life chances [Breen 2005].

Currently, we can meet some of the most common variants. In Western Europe, where class voting has a longer tradition, and where more relevant data from questionnaire surveys are available, the authors usually use a more structured approach to social class measurement [Mainwaring - Torcal - Somma 2015]. This approach examines, in particular, the employment position of an individual in the labour market. The main reason for using this concept is primarily the general awareness of the occupational profession as a clear sign of social status, in other words, it is an easy-to-understand indicator of the position of the individual within the social structure [Lambert - Bihagen 2012; ConnellyGayle - Lambert 2016]. Also, this occupation-based measure is more stable and better reflects the inclusion of an individual in the social structure [Parkin 1971; Rose - Pevalin 2003; Goldthorpe - McKnight 2006].

One of the most widespread class schemes is the structure designed by Erikson, Goldthorpe and Portocarero (EGP). This scheme is the most influential model of social stratification in social sciences [Evans 1992]. However, in the questionnaire surveys in Latin American countries, such detailed information is not included, with a few exceptions, so it is not possible to monitor the development of class voting using the EGP scheme in individual years. Fortunately, this is not always the case, and with the example of Colombia we can also use this model of social structure. This scheme and its theoretical approach has become a basis for other similar schemes in social sciences, e.g. ESeC, NS-SEC [ConnellyGayle-Lambert 2016: 4].

In 2015 Mainwaring et al. compiled a modified class scheme on the basis of the EGP scheme. To the current five categories (service class, petty bourgeoisie, routine non-manual, skilled and unskilled workers) they added the sixth, the poor self-employed. They argue that the EGP scheme was developed for Western post-industrial countries and that they do not fully reflect the specifics of other regions, in this case Latin America. The authors are right that the category of poor self-employed is crucial to understanding class structure in Latin America [Mainwaring - Torcal - Somma 2015].

Another way of measuring social class is the economic level of the individual. This approach has a tradition in the United States [Handlin 2013] and is most often measured either by household wealth or by household income. Some other authors [e.g. Savage et al. 2013; Lewis-Beck - Ratto 2013] also prefer research of the economic vote in Latin America. According to Filmer and Pritchett these components of household wealth represent the long-term economic status of households and that eliminating short-term economic outages, such as household income, because of high degrees of income churning [Jarvis Jenkins 1997; Filmer - Pritchett 2001; Jenkins - Van Kerm 2009].

There are also attempts to combine these measurements in the form of a class structure based on a socio-economic level [Lupu 2010; Handlin 2013]. In his work Handlin has created composite scales and used several schemas based on basic socio-economic data - income, wealth, and education. According to Handlin these models "allow scholars to capture more fully the range of content associated with the social class concept, offering another perspective on economic well-being and market position as well as a more robust measure of social status" [Handlin 2013: 161]. 
In this paper, several models will be compared, at first the occupation-based level models and also models of the socio-economic level. We will see if we can find some common elements.

\section{Data, models and methods}

The data was drawn from the Latin American Public Opinion Project (LAPOP), the AmericasBarometer database of 2006, 2007, 2012 and 2013. In these 4 years there were significantly fewer missing values in the occupation variable. The number of cases in each model varies depending on the missing values.

\section{EGP Structure}

As mentioned above, EGP structure is most commonly used in class voting research. More often, collapsed versions with seven, five, or even three class categories appear in the works. In that case, however, a lot of information has already disappeared and such a version with only three categories cannot tell us much about the nature of class voting.

To compare different models of social structure, two versions were used in this article, one with 11 classes and one with 6 classes. At first, the individuals were divided into the following 11 categories: Professional, manager; Technician; Office worker; Merchant; Peasant or farmer; Farmhand; Artisan; Domestic service workers; other services; Skilled worker; and Unskilled worker.

The second version, according to Mainwaring et al. [2015] should reflect a more Latin American specification. It comes back from a classic EGP collapsed version with 5 classes and a poor self-employed class has been added. The categories are as follows: the service class (large owners, professionals, administrators, managers and high-level supervisors); the petty bourgeoisie (small owners, farmers and self-employed workers in primary production); the routine non-manual (workers in administration and commerce and sales personnel); skilled worker; unskilled worker and the poor self-employed [Mainwaring Torcal-Somma 2015].

\section{Household Wealth Index}

The household wealth index (HWI) is based on information of the number of household components owned. In the AmericasBarometer questionnaire survey in Colombia, the database includes the following information in all survey years: access or ownership of; TV, refrigerator, fixed telephone, motorcycle, mobile phone, vehicle, washing machine, microwave, drinking water, bathroom and computer. Missing values were replaced by zero (0). The number of vehicles $(0,1,2,3$ and more) has been recoded to yes/owned (1) and no/ not owned (0). Some years of questionnaire surveys include other goods: home internet, a flat-screen TV, or a sanitary system. However, for the comparison between individual years, it is necessary to unify data and to use only the components that are available in all the years of the questionnaire survey, i.e. excepting the $\mathrm{a} / \mathrm{m} 11$ items. The wealth index of each household was compiled according to the following formula [Córdova 2009]: 


$$
y_{i}=\alpha_{1}\left(\frac{x_{1}-\bar{x}_{1}}{s_{1}}\right)+\alpha_{2}\left(\frac{x_{2}-\bar{x}_{2}}{s_{2}}\right)+\ldots+\alpha_{k}\left(\frac{x_{k}-\bar{x}_{k}}{s_{k}}\right)
$$

where $\bar{x}_{\mathrm{k}}$ a s $\mathrm{k}_{\mathrm{k}}$ are the mean and standard deviation of asset $x_{\mathrm{k}}$, and a represents the weight for each variable $x_{\mathrm{k}}$ for the first principal component. This formula is based on Principal Component Analysis (PCA) method which was popularized by Filmer and Pritchett [2001].

As soon as each respondent was assigned a wealth index, they were all divided into four approximately equal quartiles. From the richest (1st quartile) to the poorest (4th quartile). The 1st quartile contains individuals whose index is within range between 10.71-7.41 (10.71-8.49). The 2 nd quartile represents the range between 7.35-5.50 (8.47-6.99). The 3rd quartile contains respondents with HWI between 5.50-4.29 (6.93-5.08) and finally the lowest quartile contains HWI between 4.27-0 (5.08-0). The values for the period $2012 / 2013$ are shown in the brackets. The mean of WHI has obviously risen between those two periods.

\section{Household Income}

The respondents as mentioned above in the paragraph of Household Wealth Index, were divided into roughly similar quartiles by household income. The 1st quartile contains individuals whose household income per month is higher than $720,000(1,100,000)$ COP. The 2nd quartile represents the range between 360,000-720,000 $(630,000-1,100,000)$ COP. The 3rd quartile contains respondents with HWI between 181,000-360,000 $(450,000-630,000)$ COP and finally the lowest quartile contains HWI which is lower than $181,000(450,000)$ COP. The values for the period 2012/2013 are shown in the brackets. In the case of household income, the quartiles are really very important, because within this period a large increase in wages took place, so it is impossible to compare both periods without these adjustments.

\section{Other variables (area/region, gender, education, age)}

The results of electoral behaviour will also be presented according to other selected variables. The variable area represents the dichotomy of the urban vs. rural, the variable region divides Colombia into six areas: the capital of Bogotá, the central region, the Pacific region, the Atlantic region, the Oriental region and the area of the national territories.

In addition to the gender variable, the age variable will be presented and its dividing line is set on 35 years, a value that roughly divides the population into two similar halves.

\section{Methods}

To assess the statistical significance of the tendency of each social class to vote for presidential candidates and for the control of marginal distribution the adjusted standardized residue will be provided represented by the following formula: 


$$
A S R_{i j}=\frac{R_{i j}}{\sqrt{o_{i j} \times\left(1-\frac{r_{i}}{N}\right) \times\left(1-\frac{s_{j}}{N}\right)}}
$$

where $\mathrm{R}_{\mathrm{ij}}$ means residuum (i.e. the difference between measured and expected frequencies), $\mathrm{o}_{\mathrm{ij}}$ is the corresponding expected frequency, $\mathrm{r}_{\mathrm{i}}$ and $\mathrm{s}_{\mathrm{j}}$ are the corresponding line and column marginal frequencies and $\mathrm{N}$ is the total number of analyzed cases.

The adjusted standardised residues (ASR) will enable a control of marginal distribution. The residues follow trends of the members of social classes to vote individual parties when marginal distribution influence is controlled. Thus, the statistical significance of the correlation between social class and option for one of the parties can be explained [Matěju Řeháková 1997]. In other words, the adjusted residue indicates a significance of the difference between empirically measured frequency and an awaited (theoretic) frequency. The higher is the absolute value of the measured adjusted residue, the higher will be the statistical significance of the ascertained relation between social class and voting. ${ }^{1}$

\section{Class voting in Colombia}

The first table provides an overview of class-based electoral behaviour using the classic EGP structure. In 2006/7, at the beginning of the second presidential term, Uribe enjoyed immense public support, who responded to Uribe's military successes in relation to the FARC-EP and also successful negotiating with the AUC. At this time, many controversies linked to these achievements, especially a number of cases and evidence of limpieza social, or evidence of the cooperation of many politicians with paramilitares, have not yet been revealed.

Still, we can find social classes that, despite Uribe's high popularity, ${ }^{2}$ preferred a rather more liberal and progressive candidate such as Carlos Gavíria. And it is not without interest that they consisted rather of higher and middle social classes of professionals, managers, technicians and educated skilled workers where we can find significant residual values.

Six years later, during the beginning of peace negotiating with FARC-EP, we can find that the position of higher classes is almost the same. But what is now more important, is the change of position of farmers, peasants and farmhands. It's quite clear that this social class voted more commonly for Juan Manuel Santos and for his approach to peace negotiation. As regards this correlation, high adjusted residues were measured in this period. This is not that surprising because of fact that in May 2013 both sides FARC-EP and the government announced the first agreement during the process of peace negotiation. This agreement included land distribution of 3 million hectares to 250,000 campesinos and guarantees of health benefits, work, education etc. [Kline 2018]. Another fact remains that the campesinos were most affected by Colombian civil conflict. In the Colombian countryside, it is quite difficult to find a person who does not have a family member or a friend who has been directly affected by this war, who has lost friends or some family member, or has just been displaced from their home.

Statistically significant deviations represent values of adjusted residues greater than 1.96 or less than -1.96.

And his Partido de la “U”, founded by Juan Manuel Santos in 2005 for support president Álvaro Uribe. 


\begin{tabular}{|c|c|c|c|c|c|c|c|c|c|c|}
\hline \multicolumn{2}{|r|}{ Z } & $\stackrel{\infty}{N}$ & $\underset{\sim}{\stackrel{D}{N}}$ & R & f & $\tilde{m}$ & $\mathcal{I}$ & $=$ & নิ & $\underset{\forall}{\stackrel{N}{*}}$ \\
\hline \multirow{11}{*}{ 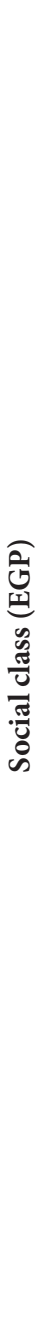 } & Unskilled worker & $\stackrel{\overbrace{}}{\longrightarrow}$ & $\stackrel{+}{0}$ & $\underset{T}{\rightarrow}$ & $\begin{array}{l}0 \\
\dot{\varphi}\end{array}$ & $\stackrel{\sim}{p}$ & $\hat{i}$ & $\hat{0}$ & $\hat{i}$ & in \\
\hline & Skilled worker & $\stackrel{10}{0}$ & $\stackrel{0}{0}$ & $\begin{array}{l}0 \\
0 \\
i\end{array}$ & $\stackrel{0}{0}$ & $\hat{i}$ & $\stackrel{\infty}{0}$ & $\overrightarrow{0}$ & $\rightrightarrows$ & $\stackrel{\infty}{\sharp}$ \\
\hline & Other services & $\stackrel{9}{i}$ & $\stackrel{0}{0}$ & ָ̊. & $\stackrel{0}{\rightarrow}$ & $\stackrel{\sim}{\sim}$ & $\stackrel{\Omega}{-}$ & $\stackrel{7}{\longrightarrow}$ & $\stackrel{\sim}{\sim}$ &  \\
\hline & Domestic service & $\begin{array}{l}\stackrel{\star}{\circ} \\
\stackrel{i}{i}\end{array}$ & $\stackrel{\operatorname{Ln}}{\rightarrow}$ & $\overrightarrow{0}$ & $\hat{i}$ & $\stackrel{10}{0}$ & $\hat{0}$ & $\hat{i}$ & $\hat{0}$ & 18 \\
\hline & Artisan & $\stackrel{\circ}{\circ}$ & $\grave{o}$ & $\hat{0}$ & $\stackrel{0}{0}$ & $\cong$ & $\stackrel{n}{0}$ & $\ddot{0}$ & $\stackrel{\infty}{0}$ & 익 \\
\hline & Farmhand & $\stackrel{\star}{i n}$ & $\begin{array}{l}0 \\
0 \\
i\end{array}$ & $\stackrel{\bullet}{\circ}$ & $\stackrel{\infty}{\rightarrow}$ & 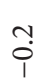 & $\stackrel{N}{0}$ & $\mathfrak{o}_{1}$ & $\stackrel{\infty}{\rightarrow}$ & $\overline{0}$ \\
\hline & Peasant or farmer & $\begin{array}{l}\stackrel{\star}{\star} \\
\stackrel{x}{\star} \\
\stackrel{+}{+}\end{array}$ & no & $\stackrel{\circ}{i}$ & $\mathfrak{p}^{n}$ & $\stackrel{\neg}{\longrightarrow}$ & $\stackrel{+}{T}$ & $\hat{o}$ & $\begin{array}{l}\text { : } \\
\text { in } \\
\text { pr }\end{array}$ & กิ \\
\hline & Merchant & $\begin{array}{l}\vdots \\
\dot{p} \\
\dot{1}\end{array}$ & $\stackrel{\circ}{\circ}$ & $\stackrel{n}{0}$ & $\stackrel{n}{n}$ & ?no & $\begin{array}{l}\infty \\
\stackrel{\varphi}{i}\end{array}$ & $\stackrel{\sim}{0}$ & $\stackrel{\infty}{-\infty}$ & $\sqrt[7]{7}$ \\
\hline & Office worker & $\vec{i}$ & $\overrightarrow{0}$ & $\stackrel{艹 \leftrightarrow}{T}$ & $\stackrel{\infty}{\infty}$ & $\stackrel{\hat{p}}{\hat{1}}$ & $\stackrel{n}{\sim}$ & $\begin{array}{l}n \\
0 \\
1\end{array}$ & $\ddot{n}$ & nิ \\
\hline & Technician & 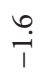 & $\stackrel{\sim}{0}$ & $\stackrel{m}{p}$ & $\stackrel{\sim}{\sim}$ & $\stackrel{\longrightarrow}{T}$ & \begin{tabular}{l}
\multirow{t}{b}{} \\
$i$ \\
$i$
\end{tabular} & $\begin{array}{l}0 \\
\dot{\varphi}\end{array}$ & 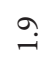 & in \\
\hline & Professional, manager & $\frac{\stackrel{\circ}{\circ}}{\stackrel{\circ}{+}}$ & $\begin{array}{l}n ? \\
\hat{\varphi}\end{array}$ & $\begin{array}{l}\stackrel{\star}{\star} \\
\stackrel{\star}{\star} \\
\stackrel{+}{+}\end{array}$ & $\ddot{0}$ & $\stackrel{\infty}{-}$ & $\vec{i}$ & $\stackrel{\star}{\sim}$ & $\stackrel{\star}{\circ}$ & $\hat{n}$ \\
\hline & 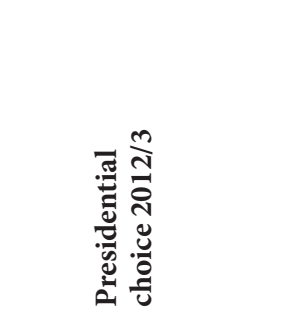 & 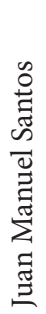 & 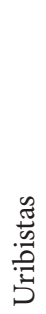 & 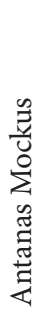 & 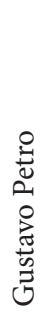 & 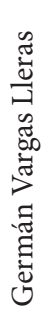 & 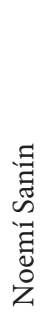 & 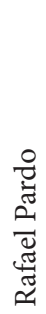 & 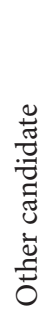 & Z \\
\hline
\end{tabular}




\begin{tabular}{|c|c|c|c|c|c|c|}
\hline & $\mathbf{Z}$ & $\stackrel{10}{=}$ & $\hat{\sigma}$ & 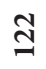 & 6 & $\stackrel{8}{+}$ \\
\hline & Unskilled worker & $\stackrel{1}{0}$ & $\stackrel{\forall}{0}$ & $\begin{array}{l}\operatorname{Ln} \\
0 \\
1\end{array}$ & $\begin{array}{l}0 \\
0 \\
i\end{array}$ & $\infty$ \\
\hline & Skilled worker & 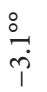 & 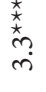 & $\hat{0}$ & $\begin{array}{l}0 \\
\dot{1}\end{array}$ & $\hat{N}$ \\
\hline & Other services & بִ & $\because$ & $\stackrel{\infty}{.}$ & $\stackrel{\star}{\stackrel{\star}{c}}$ & $\vec{D}$ \\
\hline & Domestic service & $\stackrel{\stackrel{*}{*}}{\stackrel{n}{m}}$ & $\begin{array}{l}\stackrel{0}{\circ} \\
\infty \\
\text { p. }\end{array}$ & $\stackrel{10}{0}$ & $\stackrel{n}{\rightarrow}$ & $\stackrel{\leftrightarrow}{q}$ \\
\hline is & Artisan & $\stackrel{\uparrow}{\uparrow}$ & $\stackrel{+}{0}$ & $\stackrel{\leftrightarrow}{-}$ & $\tilde{p}_{i}^{n}$ & $\stackrel{2}{2}$ \\
\hline $\begin{array}{l}\text { के } \\
\text { ज़ }\end{array}$ & Farmhand & $\stackrel{\circ}{i}$ & $\stackrel{\infty}{\rightarrow}$ & $\begin{array}{l}0 \\
0 \\
i\end{array}$ & $\begin{array}{l}0 \\
0 \\
\end{array}$ & $ํ$ \\
\hline & Peasant or farmer & $\hat{o}$ & $\stackrel{+}{0}$ & $\begin{array}{l}n ? \\
0 \\
i\end{array}$ & $\hat{i}$ & $\stackrel{M}{=}$ \\
\hline & Merchant &  & $\stackrel{\circ}{\stackrel{i}{i}}$ & $\stackrel{\uparrow}{i}$ & $\overrightarrow{0}$ & సి \\
\hline & Office worker & $\begin{array}{l}0 \\
0 \\
1\end{array}$ & $\stackrel{\infty}{0}$ & $\overrightarrow{0}$ & $\stackrel{+}{i}$ & for \\
\hline & Technician & $\stackrel{\stackrel{i}{i}}{i}$ & 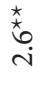 & $\stackrel{\sim}{0}$ & $\stackrel{\leftrightarrow}{-}$ & 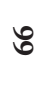 \\
\hline & Professional, manager & $\begin{array}{l}\stackrel{\circ}{\circ} \\
\stackrel{\sim}{+}\end{array}$ & 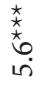 & $\hat{i}$ & $\stackrel{0}{-}$ & 2 \\
\hline & 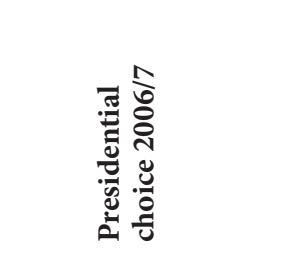 & 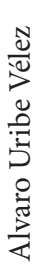 & 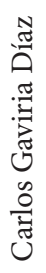 & 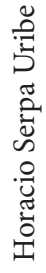 & 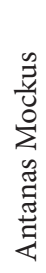 & Z \\
\hline
\end{tabular}


If we use a specific schema for Latin American countries, which is the Mainwaring's model, we can find many similarities. Table 2 presents a model with 6 social classes. It can be seen, that the residual values for the service class and skilled workers show similarities with the classic EGP scheme which was mentioned above. Individuals within the service class tended to vote rather for the progressive candidates Carlos Gaviria (Alternative Democratic Pole) and Antanas Mockus (Green Alliance), or for Germán Vargas Lleras (Radical Change), who was offering a program focused on the liberal economy, which of course was attractive for wealthy voters from higher classes. We can see the same results with the classic scheme. A lot of peasants, farmers and farmhands belonging to the poor self-employed class, preferred Santos in 2012/3; this was higher than expected in the independent situation.

Table 2: Class voting using specific EGP schema for Latin American countries [Mainwaring Torcal - Somma 2015]; 6 categories

\begin{tabular}{|l|c|c|c|c|c|c|r|}
\hline \multirow{2}{*}{$\begin{array}{l}\text { Presidential } \\
\text { choice 2006/7 }\end{array}$} & $\begin{array}{c}\text { Service } \\
\text { class }\end{array}$ & $\begin{array}{c}\text { Petty } \\
\text { bour- } \\
\text { geoisie }\end{array}$ & $\begin{array}{c}\text { Routine } \\
\text { Non- } \\
\text { manual }\end{array}$ & $\begin{array}{c}\text { Skilled } \\
\text { worker }\end{array}$ & $\begin{array}{c}\text { Unskilled } \\
\text { worker }\end{array}$ & $\begin{array}{c}\text { Poor } \\
\text { self- } \\
\text { employed }\end{array}$ & N \\
\hline Alvaro Uribe Vélez & $-3.2^{\circ \circ}$ & 1.7 & -1.1 & $-2.1^{\circ}$ & 1.7 & 1.3 & $\mathbf{7 4 7}$ \\
\hline Carlos Gaviria Díaz & $4.1^{* * *}$ & $-2.1^{\circ}$ & 0.3 & $3.4^{* * *}$ & -1.1 & $-2.0^{\circ}$ & $\mathbf{1 4 5}$ \\
\hline Horacio Serpa Uribe & -0.9 & 0.0 & 1.3 & -1.0 & -0.8 & 0.9 & $\mathbf{7 7}$ \\
\hline Antanas Mockus & $2.1^{*}$ & 0.4 & 0.1 & -0.5 & -1.1 & -0.9 & $\mathbf{5}$ \\
\hline $\mathbf{N}$ & $\mathbf{1 0 6}$ & $\mathbf{3 1 4}$ & $\mathbf{1 7 4}$ & $\mathbf{4 7}$ & $\mathbf{2 0 1}$ & $\mathbf{1 3 2}$ & $\mathbf{9 7 4}$ \\
\hline
\end{tabular}

\begin{tabular}{|c|c|c|c|c|c|c|c|}
\hline \multirow[b]{2}{*}{$\begin{array}{l}\text { Presidential } \\
\text { choice 2012/3 }\end{array}$} & \multicolumn{6}{|c|}{ Social class (EGP-M) } & \multirow[b]{2}{*}{$\mathbf{N}$} \\
\hline & $\begin{array}{l}\text { Service } \\
\text { class }\end{array}$ & $\begin{array}{c}\text { Petty } \\
\text { bour- } \\
\text { geoisie }\end{array}$ & $\begin{array}{l}\text { Routine } \\
\text { Non- } \\
\text { manual }\end{array}$ & $\begin{array}{l}\text { Skilled } \\
\text { worker }\end{array}$ & $\begin{array}{l}\text { Unskilled } \\
\text { worker }\end{array}$ & $\begin{array}{c}\text { Poor } \\
\text { self- } \\
\text { employed }\end{array}$ & \\
\hline Juan Manuel Santos & $-3.1^{\circ \circ}$ & -0.7 & $-2.6^{\circ \circ}$ & -1.5 & 1.8 & $4.1^{\star * *}$ & 457 \\
\hline Uribistas & -0.7 & 0.4 & -0.4 & 0.6 & -0.4 & 0.2 & 172 \\
\hline Antanas Mockus & $3.6^{* * *}$ & 0.6 & 0.5 & 0.7 & -0.4 & $-3.4^{000}$ & 50 \\
\hline Gustavo Petro & 1.7 & -1.8 & 1.3 & 1.1 & 0.9 & -1.7 & 29 \\
\hline Germán Vargas Lleras & $3.1^{\star *}$ & 0.9 & -1.4 & -0.7 & 0.6 & -1.9 & 18 \\
\hline Noemí Sanín & 1.8 & -0.4 & 0.5 & -0.9 & 0.4 & -0.8 & 6 \\
\hline Rafael Pardo & 1.8 & 0.5 & 0.5 & -0.9 & -0.9 & -0.8 & 6 \\
\hline Other candidate & -0.1 & 0.5 & $3.1^{* *}$ & 1.0 & $-2.1^{\circ}$ & -1.6 & 178 \\
\hline $\mathbf{N}$ & 99 & 223 & 92 & 100 & 109 & 293 & 916 \\
\hline
\end{tabular}

Source: [AmericasBarometer 2006, 2007, 2012, 2013], author's Fig. and calculations

The topic of peace negotiating was much more important to the most vulnerable class. As mentioned above, many of campesinos belong to the poor self-employed and this class 
during the war suffered more than others and this class more than any other was longing for peace. It means that class-concerned topics in this period were not so important. On that score left-wing candidates Mockus or Petro could not rely on classic voters.

As a summary of results of the models based on occupation level measures, a classic EGP scheme with 11 class categories has, as expected, provided more detailed information due to the fact that the number of independent variables was relatively high. Contrary to the narrow and specific Latin American scheme with 6 categories, we learned mainly about the tendency of campesinos to vote for Santos, a candidate who was the most suitable alternative for this social class. The reason was mentioned above, Santos was not a progressive salvation, but for such a vulnerable and haunted class as the campesinos, this peace-oriented president represented hope for them. Relatively surprising was the tendency of higher classes to vote rather for left-wing presidential candidates, in 2006/7 it was Carlos Gavíria and 6 years later "green" Antanas Mockus.

We can see that with the occupation level-based models the class voting is not quite clear in Colombia. Rather than class issues, the Colombians are interested in topics related to solving a long-standing conflict in their country.

Table 3: Class voting using socio-economic level of Household Income

\begin{tabular}{|l|c|c|c|c|c|}
\hline \multirow{2}{*}{$\begin{array}{l}\text { Presidential } \\
\text { choice 2006/7 }\end{array}$} & \multicolumn{4}{|c|}{ Income quartile } & \multirow{2}{*}{ N } \\
\cline { 2 - 5 } & I & II & III & IV & \\
\hline Alvaro Uribe Vélez & $-4.8^{\text {ooo }}$ & -1.3 & $3.5^{\star * *}$ & $3.2^{* *}$ & $\mathbf{1 , 0 4 8}$ \\
\hline Carlos Gaviria Díaz & $5.1^{\star * *}$ & 1.6 & $-3.9^{\circ \circ}$ & $-3.4^{\text {ooo }}$ & $\mathbf{2 0 2}$ \\
\hline Horacio Serpa Uribe & 0.1 & 0.0 & 0.2 & -0.3 & $\mathbf{1 1 3}$ \\
\hline Antanas Mockus & $2.8^{\star *}$ & -0.3 & -1.7 & -1.0 & $\mathbf{1 0}$ \\
\hline $\mathbf{N}$ & $\mathbf{4 1 0}$ & $\mathbf{3 3 9}$ & $\mathbf{3 0 7}$ & $\mathbf{3 1 7}$ & $\mathbf{1 , 3 7 3}$ \\
\hline
\end{tabular}

\begin{tabular}{|l|c|c|c|c|c|}
\hline \multirow{2}{*}{$\begin{array}{l}\text { Presidential } \\
\text { choice 2012/3 }\end{array}$} & \multicolumn{4}{|c|}{ Income quartile } & \multirow{2}{*}{ N } \\
\cline { 2 - 5 } & I & II & III & IV & \\
\hline Juan Manuel Santos & $-4.6^{\circ \circ}$ & -1.2 & 0.8 & $5.1^{* * *}$ & $\mathbf{6 8 7}$ \\
\hline Uribistas & -0.2 & 0.9 & 1.9 & $-2.6^{\circ \circ}$ & $\mathbf{2 7 6}$ \\
\hline Antanas Mockus & $4.4^{* * *}$ & -0.4 & -1.3 & $-2.8^{\circ \circ}$ & $\mathbf{6 7}$ \\
\hline Gustavo Petro & 0.9 & $2.0^{*}$ & -1.2 & -1.8 & $\mathbf{3 9}$ \\
\hline Germán Vargas Lleras & $2.3^{\star}$ & 0.0 & -1.6 & -0.9 & $\mathbf{2 8}$ \\
\hline Noemí Sanín & 0.7 & 0.9 & -1.8 & 0.2 & $\mathbf{1 1}$ \\
\hline Rafael Pardo & -0.7 & -1.2 & -0.4 & $2.3^{*}$ & $\mathbf{1 1}$ \\
\hline Other candidate & $2.3^{\star}$ & 0.1 & -0.7 & -1.8 & $\mathbf{2 7 4}$ \\
\hline N & $\mathbf{3 7 9}$ & $\mathbf{3 4 4}$ & $\mathbf{3 2 2}$ & $\mathbf{3 4 8}$ & $\mathbf{1 , 3 9 3}$ \\
\hline
\end{tabular}

Source: [AmericasBarometer 2006, 2007, 2012, 2013], author's Fig. and calculations 
Now we can focus on results of models based on socio-economic measures. Table 3 represents the results of class voting based on the household income. As with previous models, this model also offers significant residual values in several cases. Uribe in 2006/7 had significant support of the lower classes. On the other hand, the number of votes of lower classes for Gavíria was much lower than expected in the independent situation. 6 years later, the residue measured by the lowest-income voters who signed up for Santos was very high. Again, this class includes especially the poor self-employed class of the Mainwaring EGP scheme, and we can find also classes of peasants and farmhands from the classic EGP scheme. Lowest classes again did not support the left-wing candidates. As mentioned above, they were more concerned with conflict resolution topics than class issues such as redistribution of wealth, social security, etc. On the other hand, higher levels were supported by more progressive candidates. A possible explanation could be that the vast majority of higher classes live in large cities, and they are not that interested in the armed conflict in the country; more likely they have interests in sustainable development or the solution of a catastrophic situation in urban transport (especially Bogotá and Cali).

Table 4: Class voting using socio-economic level of Household Wealth Index

\begin{tabular}{|l|c|c|c|c|c|}
\hline \multirow{2}{*}{$\begin{array}{l}\text { Presidential } \\
\text { choice 2006/7 }\end{array}$} & \multicolumn{4}{|c|}{ Wealth Index quartile } & \multirow{2}{*}{ N } \\
\cline { 2 - 5 } & I & II & III & IV & \\
\hline Alvaro Uribe Vélez & $-3.7^{\circ \circ \circ}$ & -1.0 & $2.4^{*}$ & $2.4^{*}$ & $\mathbf{1 , 2 3 0}$ \\
\hline Carlos Gaviria Díaz & $4.5^{* * *}$ & 1.0 & $-2.0^{\circ}$ & $-3.5^{\circ 0 \circ}$ & $\mathbf{2 3 1}$ \\
\hline Horacio Serpa Uribe & -1.1 & 0.4 & -0.5 & 1.2 & $\mathbf{1 3 3}$ \\
\hline Antanas Mockus & $3.7^{* * *}$ & -0.5 & -2.0 & -1.2 & $\mathbf{1 1}$ \\
\hline $\mathbf{N}$ & $\mathbf{4 0 1}$ & $\mathbf{4 0 1}$ & $\mathbf{4 1 3}$ & $\mathbf{3 9 0}$ & $\mathbf{1 , 6 0 5}$ \\
\hline
\end{tabular}

\begin{tabular}{|l|c|c|c|c|c|}
\hline \multirow{2}{*}{$\begin{array}{l}\text { Presidential choice } \\
\mathbf{2 0 1 2 / 3}\end{array}$} & \multicolumn{4}{|c|}{ Wealth Index quartile } & \multirow{2}{*}{ N } \\
\cline { 2 - 5 } & I & II & III & IV & \\
\hline Juan Manuel Santos & $-3.7^{\circ \circ \circ}$ & $-3.4^{\text {ooo }}$ & $2.8^{\star *}$ & $4.0^{* * *}$ & $\mathbf{7 7 9}$ \\
\hline Uribistas & -1.4 & 1.7 & 0.4 & -0.7 & $\mathbf{3 0 5}$ \\
\hline Antanas Mockus & $3.4^{* * *}$ & 1.7 & $-2.5^{\circ}$ & $-2.5^{\circ}$ & $\mathbf{7 7}$ \\
\hline Gustavo Petro & 1.7 & -1.0 & 1.7 & $-2.1^{\circ}$ & $\mathbf{4 7}$ \\
\hline Germán Vargas Lleras & $3.1^{* *}$ & 0.9 & -1.4 & $-2.4^{\circ}$ & $\mathbf{3 4}$ \\
\hline Noemí Sanín & 0.3 & 0.6 & -0.4 & -0.4 & $\mathbf{1 2}$ \\
\hline Rafael Pardo & -0.3 & 0.8 & -0.3 & -0.3 & $\mathbf{1 1}$ \\
\hline Other candidate & $2.3^{\star}$ & 1.5 & $-2.7^{\circ \circ}$ & -1.1 & $\mathbf{3 0 4}$ \\
\hline N & $\mathbf{3 4 5}$ & $\mathbf{3 9 8}$ & $\mathbf{3 4 2}$ & $\mathbf{4 8 4}$ & $\mathbf{1 , 5 6 9}$ \\
\hline
\end{tabular}

Source: [AmericasBarometer 2006, 2007, 2012, 2013], author's Fig. and calculations 
Table 4 offers nearly the same results and presents the class voting using a model based on the household wealth index. Again, the higher class preferred the more progressive candidates, while the lower classes voted rather for conservative ones. It is not a unique situation in Latin America, it happens when the campaign is more focused on civic issues rather than class issues [Mainwaring - Torcal - Somma 2015: 78-79].

The educated urban higher-middle class represents the voters of progressive left-wing candidates in Colombia. A good proof can be seen from the results of Table 5. Mainwaring et al. have made the same conclusion. What is interesting here, however, are gender results. There is a big difference between men and women. Actually, in the countries with the lower level of female professionals, women are more conservative than men and significantly rather voting for more right-wing candidates [Morgan 2015]. As for the variable of age, the fact that older voters are much more conservative than their younger counterparts is confirmed here.

Table 5: Class voting using other variables (area, gender, education and age)

\begin{tabular}{|l|c|c|c|c|}
\hline \multirow{2}{*}{$\begin{array}{l}\text { Presidential } \\
\text { choice 2006/7 }\end{array}$} & \multicolumn{4}{|c|}{ Other variables } \\
\cline { 2 - 5 } & $\begin{array}{c}\text { Area: } \\
\text { Urban }\end{array}$ & $\begin{array}{c}\text { Gender: } \\
\text { Male }\end{array}$ & $\begin{array}{c}\text { Education: } \\
\mathbf{1 0} \text { yrs }+\end{array}$ & $\begin{array}{c}\text { Age: } \\
\mathbf{3 5} \text { yrs + }\end{array}$ \\
\hline Alvaro Uribe Vélez & $-2.5^{\circ}$ & $-4.3^{\text {ooo }}$ & $-8.2^{\text {oo० }}$ & $2.1^{\star}$ \\
\hline Carlos Gaviria Díaz & $2.4^{*}$ & $3.9^{* * *}$ & $7.7^{* * *}$ & $-3.0^{\circ \circ}$ \\
\hline Horacio Serpa Uribe & 0.2 & 1.0 & 1.8 & 1.3 \\
\hline Antanas Mockus & 1.9 & $2.1^{\star}$ & $3.3^{* * *}$ & $-2.6^{\circ \circ}$ \\
\hline
\end{tabular}

\begin{tabular}{|l|c|c|c|c|}
\hline \multirow{2}{*}{$\begin{array}{l}\text { Presidential } \\
\text { choice 2012/3 }\end{array}$} & \multicolumn{4}{|c|}{ Other variables } \\
\cline { 2 - 5 } & $\begin{array}{c}\text { Area: } \\
\text { Urban }\end{array}$ & $\begin{array}{c}\text { Gender: } \\
\text { Male }\end{array}$ & $\begin{array}{c}\text { Education: } \\
\mathbf{1 0} \text { yrs }+\end{array}$ & $\begin{array}{c}\text { Age: } \\
\text { 35 yrs + }\end{array}$ \\
\hline Juan Manuel Santos & $-2.3^{\circ}$ & -1.9 & $-7.2^{\text {ooo }}$ & $4.9^{* * *}$ \\
\hline Uribistas & -0.2 & -0.7 & -0.9 & -0.1 \\
\hline Antanas Mockus & $2.3^{\star}$ & 1.6 & $4.5^{* * *}$ & -1.2 \\
\hline Gustavo Petro & 1.3 & $2.1^{\star}$ & $3.4^{* * *}$ & 0.5 \\
\hline Germán Vargas Lleras & 1.9 & 0.6 & $2.7^{* *}$ & -0.1 \\
\hline Noemí Sanín & 1.2 & $-2.4^{\circ}$ & $2.8^{* *}$ & -0.8 \\
\hline Rafael Pardo & -1.8 & -1.0 & -1.7 & -0.2 \\
\hline Other candidate & 0.7 & 1.8 & $4.8^{* * *}$ & $-5.3^{\circ \circ 0}$ \\
\hline
\end{tabular}

Source: [AmericasBarometer 2006, 2007, 2012, 2013], author's Fig. and calculations

The last Table 6 shows regional voting results. Two important pieces of information can be found therein. Firstly, the Pacific region, with its cultural diversity differs much more from the others and chooses rather alternative candidates and is very anti-Uribista. The Pacific region - especially departments Cauca and Valle del Cauca - was also a territory 
where guerrilla groups were mostly active for decades. In contrast, the Oriental region significantly prefers voting for Uribistas. The results of the vote in Bogotá are significant only in years 2006/7 and they are the evidence of previous results of class voting. Bogotá voted for progressive left-wing candidates.

Table 6: Regional voting using variable of region

\begin{tabular}{|c|c|c|c|c|c|c|c|}
\hline \multirow[b]{2}{*}{$\begin{array}{l}\text { Presidential } \\
\text { choice 2006/7 }\end{array}$} & \multicolumn{6}{|c|}{ Region } & \multirow[b]{2}{*}{$\mathbf{N}$} \\
\hline & 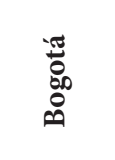 & U⿺辶ّ & 苞 & : & 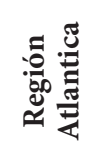 & 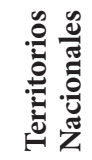 & \\
\hline Alvaro Uribe Vélez & $-3.9^{\circ 00}$ & $2.6^{\star *}$ & $3.5^{\star * *}$ & $-4.1^{000}$ & 0.3 & 1.0 & 1,230 \\
\hline Carlos Gaviria Díaz & $4.2^{\star \star \star *}$ & -0.8 & $-3.9^{\circ 00}$ & $3.9^{* * *}$ & $-2.2^{\circ}$ & -0.3 & 231 \\
\hline Horacio Serpa Uribe & -0.9 & $-2.5^{\circ}$ & -0.2 & 1.5 & $2.7^{\star *}$ & -1.0 & 133 \\
\hline Antanas Mockus & $5.4^{\star * \star}$ & -1.9 & -0.9 & -0.5 & -1.1 & -0.6 & 11 \\
\hline $\mathbf{N}$ & 237 & 394 & 325 & 233 & 369 & 47 & 1,605 \\
\hline
\end{tabular}

\begin{tabular}{|c|c|c|c|c|c|c|c|}
\hline \multirow[b]{2}{*}{$\begin{array}{l}\text { Presidential } \\
\text { choice } 2012 / 3\end{array}$} & \multicolumn{6}{|c|}{ Region } & \multirow[b]{2}{*}{$\mathbf{N}$} \\
\hline & 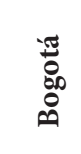 & U⿺辶ِّ & 퓰 & 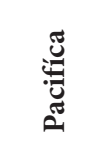 & 苞 & 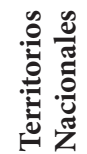 & \\
\hline Juan Manuel Santos & -0.5 & 1.3 & -1.0 & 1.3 & -0.9 & -0.3 & 779 \\
\hline Uribistas & -1.8 & 0.8 & $3.9^{* * *}$ & $-4.2^{\circ 00}$ & 0.8 & 0.6 & 305 \\
\hline Antanas Mockus & 1.3 & 0.2 & -0.7 & 0.8 & $-2^{\circ}$ & 1.3 & 77 \\
\hline Gustavo Petro & 0.8 & $-2.5^{\circ}$ & -1.1 & -0.3 & $3.1^{\star *}$ & -0.3 & 47 \\
\hline Germán Vargas Lleras & 1.5 & 0.8 & -0.2 & -1.0 & -1.1 & 0.0 & 34 \\
\hline Noemí Sanín & 1.5 & -1.8 & 0.6 & -0.2 & 0.2 & -0.6 & 12 \\
\hline Rafael Pardo & 1.7 & -1.0 & 0.0 & -0.8 & 0.4 & -0.6 & 11 \\
\hline Other candidate & 0.1 & -1.1 & -1.9 & $2.8^{\star *}$ & 0.4 & -0.6 & 304 \\
\hline $\mathbf{N}$ & 264 & 330 & 293 & 290 & 348 & 44 & 1,569 \\
\hline
\end{tabular}

Source: [AmericasBarometer 2006, 2007, 2012, 2013], author's Fig. and calculations

\section{Conclusion}

The results of class-based behaviour in Colombia have brought interesting information. There are not many differences between the results of individual stratification models. The interesting thing is in fact, that we can find reverse class voting in Colombia. Each stratification model offered almost the same result. The higher-middle classes vote rather 
for progressive centre left-wing candidates while the lower classes vote more for most conservative candidates. One of the explanations can be following: The better environment, sustainable development and solving of poor and crowded urban transport are more important topics for the educated voters in large cities. Thanks to the political decentralization [Eaton 2020] in recent years, the mayor's office in Bogotá has been regularly filled by candidates from more progressive parties (Antanas Mockus, Gustavo Petro, Claudia López etc.) and only confirms the conclusions of this article. Neoliberal parties failing to grasp the above issues and losing to the progressive parties, which often leads to a left turn in Latin American capitals [Angotti 2013].

On the contrary, the topic of armed conflict in the countryside is not so important for them compared to the vulnerable classes. For the rural lower classes, that were most affected by a civil war, the most important issue is a conflict resolution. And this could be a reason for the support for Uribe in 2006/7 and later for Santos in 2012/3. In the first case, Uribe was very popular and many of his controversies and scandals were not proven and also during his presidency the number of FARC-EP members significantly decreased. In the second case, mostly the campesinos were very tired of a never-ending conflict and Santos was a chance to finally reach a peace treaty. The most significant support for Santos came from the class of peasants and farmers. The class which suffered a lot during the last 50 years. For that reason, the class issue in the case of Colombia is important, but it is not so clear because of the topic of a civil war between government, guerrilla groups and paramilitares. This topic is for very good reasons for some classes more important than classic class issues, e.g. social redistribution of income and wealth, social security or issues of education. It will be interesting to observe the future in Colombia. When data from 2018 elections will be available, it would be clearer whether the results of the 2006/7 and $2012 / 3$ class votes were just a question of actual issues in the society or whether they have deeper roots.

\section{Acknowledgements}

This paper is a part of the specific research project of the Philosophical faculty of the Hradec Králové University "Different measures of social class - different results of class voting?".

\section{Bibliography}

Angotti, Tom [2013]. Urban Latin America: Violence, Enclaves, and Struggles for Land. Latin American Perspectives 40 (2).

Breen, Richard [2005]. Foundations of a Neo-Weberian Class Analysis. In. Wright, Elin O. (ed.). Approaches Class Analysis. Cambridge: Cambridge University, pp. 31-50.

Connelly, Roxanne - Gayle, Vernon - Lambert, Paul S. [2016]. A Review of occupation-based social classifications for social survey research. Methodological Innovations 9: 1-14.

Córdova, Abby [2009]. Methodological Note: Measuring Relative Wealth using Household Asset Indicators. AmericasBarometer Insights 2009 (6): 1-9.

Eaton, Kent [2020]. Bogotás Left Turn: Counter Neoliberalization in Colombia. International Journal of Urban and Regional Research 44 (1). 
Evans, Geoffrey [1992]. Testing the validity of the Goldthorpe class schema. European Sociological Review 8 (3): 211-232.

Filmer, Deon - Pritchett, Lant H. [2001]. Estimating Wealth Effect Without Expenditure Data or Tears: An Application to Educational Enrollments in States of India. Demography 38 (1): 115-132.

Goldthorpe, John H. - McKnight, Abigail [2006]. The economic basis of social class. In. Morgan, Stephen L. - Grusky, David B. - Fields, Gary S. (eds.). Mobility and Inequality: Frontiers of Research in Sociology and Economics. Stanford: Stanford University Press, pp. 109-136.

Handlin, Samuel [2013]. Survey Research and Social Class in Venezuela: Evaluating Alternative Measures and Their Impact on Assessments of Class Voting. Latin American Politics and Society 55 (1): 141-167.

Hartlyn, Jonathan - Dugas, John [1999]. Colombia: The Politics of Violence and Democratic Transformation. In. Diamond, Larry - Hartlyn, Jonathan - Linz, Juan - Lipset, Samuel M. (eds.). Democracy in Developing Countries: Latin America Edition. Lynne Rienner Pub, pp. 248-307.

Jarvis, Sarah - Jenkins, Stephen P. [1997]. Low income dynamics in 1990s Britain. Fiscal Studies 18 (2): 123-143.

Jenkins, Stephen P. - Van Kerm, Philippe [2009]. The measurement of economic inequality. In. Nolan, Brian - Salverda, Wiemer - Smeeding, Timothy M. (eds.). Economic Inequality. Oxford: Oxford University Press, pp. 40-69.

Kline, Harvey F. [2018]. Colombia: Is Guerrilla Violence Near Its End? In. Kline, Harvey F. - Wade, Christine J. - Wiarda, Howard J. (eds.). Latin American Politics and Development. New York: Westview press, pp. 169-194.

LaRosa, Michael J. - Mejía, Germán R. [2017]. Colombia. A Concise Contemporary History. Lanham: Rowman \& Littlefield.

Lambert, Paul - Bihagen, Erik [2012]. Stratification Research and Occupation-based Social Classifications. In. Lambert, Paul S. - Connelly, Roxanne - Blackburn, Robert M. - Gayle, Vernon (eds.). Social Stratification: Trends and Processes. Farnham: Ashgate, pp. 13-28.

Lewis-Beck, Michael S. - Ratto, Maria Celeste [2013]. Economic Voting in Latin American: A General Model. Electoral Studies 32 (3): 489-493.

Lupu, Noam [2010]. Who votes for 'chavismo'? Class Voting in Hugo Chávez’s Venezuela. Latin American Research Review 45 (1): 7-32.

Mainwaring, Scott - Torcal, Mariano - Somma, Nicolás M. [2015]. The Left and the Mobilization of Class Voting in Latin America. In. Carlin, Ryan E. - Singer, Matthew M. - Zechmeister, Elizabeth J. (eds.). The Latin American Voter. Ann Arbor: University of Michigan Press, pp. 69-98.

Matějů, Petr - Řeháková, Blanka [1997]. Obrat doleva nebo proměna vzorců volebního chování sociálních tříd? Working paper of project "Sociální trendy" 2/1997, Sociologický ústav AV ČR.

Morgan, Jana [2015]. Gender and the Latin American Voter. In. Carlin, Ryan E. - Singer, Matthew M. Zechmeister, Elizabeth J. (eds.). The Latin American Voter. Ann Arbor: University of Michigan Press, pp. 143-168.

Parkin, Frank [1971]. Class Inequality and Political Order: Social Stratification in Capitalist and Communist Societies. New York: Praeger.

Rose, David - Pevalin, David J. [2003]. The NS-SEC explained. In. Rose, David - Pevalin, David J. (eds.). A Researcher's Guide to the National Statistics Socio-Economic Classification. London: SAGE, pp. 28-43.

Safford, Frank - Palacios, Marco [2002]. Colombia. Fragmented Land, Divided Society. New York: Oxford University Press.

Savage, Mike - Devine, Fiona - Cunningham, Niall - Taylor, Mark - Li, Yaojun - Hjellbrekke, Johs - Le Roux, Brigitte - Friedman, Sam - Miles, Andrew [2013]. A new model of social class: Findings from the BBC's Great British Class Survey experiment. Sociology 47 (2): 219-250.

LAPOP (Latin American Public Opinion Project). The Americas Barometer by the Latin American Public Opinion Project (LAPOP). Datasets: Colombia 2004-2016. Available at: <https://www.vanderbilt.edu /lapop/raw-data.php>.

Jan Pumr $\left({ }^{*} 1984\right)$ is an external PhD candidate at the department of Political Sciences of Philosophical faculty of the University of Hradec Králové. His research interest concentrates on social classes and class-based voting in Latinamerican countries. 